\title{
Einstein the deist and Flew the theist viewed from a Christian perspective
}

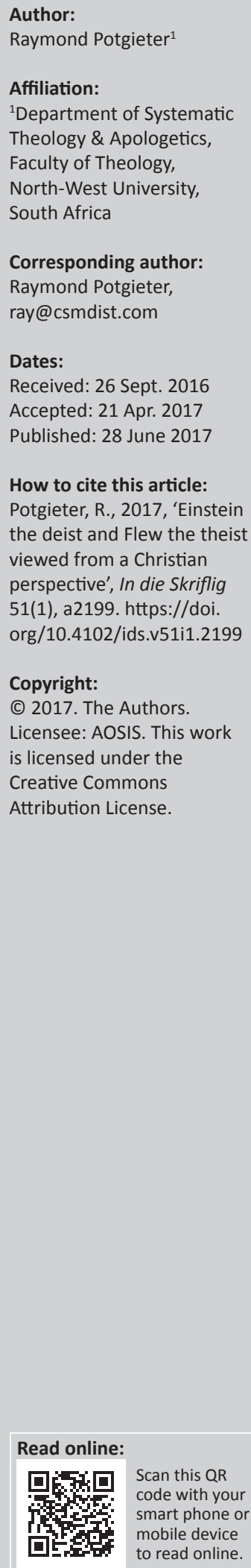

Both Albert Einstein and Antony Flew had various religious influences during their adolescent years. But both turned away from Christianity due to rational inconsistencies that, in their views, made faith incompatible to science, on the one hand, and to reason, on the other. Einstein retained a deistic sense of appreciation of the universe while Flew retreated into atheism. The former expressed his deism in Spinozian terms and never actually seriously questioned the god of Spinoza. Flew, on the other hand, embarked on atheism based on rationality on the Socratic premise that he would follow where the evidence led. While Einstein remained a deist to the end, Flew followed the evidence converted to deism and then to theism. Insights into these two great rational thinkers will serve to remind the church and zealous evangelicals that a more deliberate account needs to be taken of a person's background, their personal philosophy and reasons for commitment to alternate beliefs. Knowing what draws thinking persons to their commitments allow for a more insightful approach to be adopted by Christians wanting to state the case for Christian theism as fulfilled in Jesus Christ.

\section{"I see nobody on the road," said Alice.}

"I only wish I had such eyes," the King remarked in a fretful tone. "To be able to see Nobody! And at that distance too!" Through the Looking Glass - Lewis Carroll (2002:210).

\section{Introduction}

For many, religious faith translates into the very fabric of their living experience. For those who claim some form of theism or deism there is, without exception, some evidence of their belief. Faith translates into some system of belief - often more overtly evident and more clearly discerned in committed Christians, Hindus, Muslims and others. A particular faith expression among Christians will, for instance, hinge upon whether it is an interpretation influenced by, among others, reformed, Pentecostal or Arminian theology, or some other theological derivation. Due to changing theological convictions Christian believers may sometimes move from one brand of theology to another. This does not mean abandoning Christianity, but a shift in conviction based upon new understanding.

To further appreciate the importance of understanding one's audience may be illustrated by some of the challenges faced by a third millennium audience. These may include the attractions of superstition, the physical transformation of one species into another or even into a chimeran Hollywood blend (Transformers) seemingly necessary for survival in fictitious worlds struggling with primeval elements such as chaos, darkness and semblances of order. For many young people it is within this context that forms of theism and deism are presented in a variety of ways. The point is this: to engage with thoughtful young people, imbued with third millennium mind-sets, requires a shift from a generic time-tested formula of God-talk to one that appreciates the commitment of persons or audiences to their own ideas about God, nature or materialism that are often the expressions of scientifically oriented worldviews.

I will focus on the particular attraction that deism had for the 20th century's most famous scientist, Albert Einstein (1879-1955). This will be followed by a brief examination of the stances held by the philosopher, Anthony Flew (1923-2010), who converted from atheism to deism and finally settled on theism. Finally, it must be clarified that when the terms deism or deist and theism or theist are used, it will be from within the generic understanding of a Judeao-Christian context unless otherwise stated and implied by the context.

This article concludes with be a brief evaluation of theism or deism's influences on the shaping of Einstein and Flew. This critical approach should serve to show the depth and commitment of rational 
persons to their beliefs. Christians will appreciate that to engage in any conversation with such individuals or audiences ${ }^{1}$ needs thorough preparation for meaningful conversations to ensue. This counters the tendency towards simplistic and generic presentations of the gospel of Jesus Christ.

\section{Understanding deism and theism ${ }^{2}$ Deism ${ }^{3}$}

From the corpus of scholarly books and articles available, it becomes clear that there is no consensus on a single form of deism (Rowe 2000:198). One has to distinguish between early and present forms of deism. Historically, deism may be traced, reflecting different stages of maturity, to Heraclitus's logos that he perceived as an overarching rational principle. Plato, for instance, spoke of a 'demiurge' responsible for fashioning and shaping the universe.

Deism may also be traced in the development of Islam (Dupré 1999:2) long before it was contended by Christianity. While deism was associated with revelation by Thomas Aquinas (1225-1274), the later 18th century deists began emphasising reason alone at the expense of revelation. Deism proved to be inadequate as a comprehensive system of belief for the encyclopaedist, Denis Diderot (1713-1784), who moved from being a deist to a sceptic and finally to an atheist ${ }^{4}$ (Vartanian 1949:46-63). This led to developing natural religion based on reason alone.

Deism spread from the continent to England and the USA. The rational mechanistic cosmologies of Galileo, Kepler and Newton served to influence many of the leading thinkers of the time. At first, the attribute of a transcendent other God was challenged, then God got side-lined and, finally, simply ignored. But to claim that God-talk was redundant was mors praematura. In the resultant vacuum a surprising twist came about. Attributes that had formerly been ascribed to God were now applied to nature itself. God's being now existed in a vacuum removed from nature. A new brand of theism was about to emerge. Such as is evident today 'Among those secular quasi-religions scientific naturalism, with or without ecological connotations ${ }^{5}$ may be the most popular' (Dupré 1999:10).

Basically, a deist believes in a solution: a god who is the creator of creation, but does not go as far as overseeing creation in the sense of governance or superintendence. Or, when seen from a strong philosophical perspective, it is the ground for:

Our values, our morals, our goals, our identities, who we are, where we are, above all how we know any of these things, it all comes from our philosophy of life - whether we know it or not

1.McGrath $(2012: 57-70)$ deals with the issue of adapting to the audience referring in particular to Acts 2 (Jews), 17 (Greek philosophers), 24-26 (Romans).

$2 . I$ am aware of the discussions surrounding models representative of reality (cf. Wartofsky 1979).

3.For the origin and historical development of the term, see Lucci (2008:17ff.).

4.Wartofsky (1979:337) suggests that Diderot used deism as a cover up for his atheist convictions.

5.Dupré (1999:10-11) finds the same applies to the principle of aesthetics.
... Many people call their philosophy a 'Religion'. (Carrier 2005:3)

Deism is the recognition of a universal creative force greater than that demonstrated by mankind, supported by personal observation of laws and designs in nature and the universe, perpetuated and validated by the innate ability of human reason coupled with the rejection of claims made by individuals and organized religions of having received special divine revelation. (Johnson 1993).

Present forms of deism may be very much part and parcel of debates among philosophers and natural scientists. The god of classical deism was impersonal - one who created the universe or world which is on a pathway guided by that creator's divine providence. To claim personal intervention from this god is to negate the inherent universal gifts of humankind - gifts such as patience, reason, compassion, love, kindness and so on, not particular to any person and not needing supernatural intervention.

In short, deism serves as a powerful argument purporting that Christianity (and other religions) had its origins in human endeavours. Consequently not one religion can claim supremacy (Lucci 2008:10).

Modern deism extended its classical take with the scientific discoveries by Freud or Jung of the unconscious. Inevitably this would also explore man's meaning on a contained earth - the search for purposefulness, humankind's dependence on the bio-sphere (Darwinism) ${ }^{6}$ and so on. To be more specific: it would be to attribute this creator's deity with human characteristics; in other words, creating a deity in man's image.

\section{Theism}

It is probably necessary to elucidate the concept of theism as it has been the subject of attempted redefinition for some years now (cf. Potgieter 2013; Van Wyk 2013). AChristian philosopher, Swinburne (1979:8), equates the meaning of the statement God exists to a person - eternal, without body, perfectly free, omnipotent, omniscient, perfectly good, creator of all things. Oppy (1992:468), no friend of theism, dismantles this as he does not accept such equivalence and will not go much beyond saying 'it would be more natural to say that God does exist, but that he is not quite as we imagined him to be'.

Clearly the former elaboration of the concept of God is an underlying acceptance of the Judaeo-Christian idea of God. ${ }^{7}$ To perceive God as sentient, benevolent and involved in human lives and their living as well as the operation of this world is also to see God in the sense of an a priori figure. Such involvement cannot be easily dismissed, as Oppy does, without seriously considering a redefinition or elimination of God as deity. Such a deity for both deism and theism would

6.This list could be developed to include Karl Marx's theory of capitalism, Einstein's relativity.

7.I am aware of the effect that the overlap between theism and theodicy brought into question varying responses due to divergent understandings of a Judaeo-Christian background in dealing with the horrors of the Holocaust. The same may be said for theism and ethics (cf. Carrier 2005). For the sake of brevity I do not pursue these lines of thinking. The above should, however, serve to illustrate this. 
be in the words of Shepherd (1975:52) a 'cosmos-explaining being' (CEB) or a 'cosmic self' whether centred in or beyond the world. At that level, logic may also posit a model or an alternative explanation not merely consequential to religion. It may also be a mind construct 'which is dependent not on religion but on purely philosophical considerations' (Shepherd 1975:52). This would alleviate tension between spirituality and non-materiality for both models.

\section{Albert Einstein (1879-1955) Einstein's credo}

It was in Caputh (1930) that Einstein drafted his Mein Glaubensbekenntnis (1932), part of which reads:

Das Schönste und Tiefste, was der Mensch erleben kann, ist das Gefühl des Geheimnisvollen. Es liegt der Religion sowie allem tieferen Streben in Kunst und Wissenschaft zugrunde. Wer dies nicht erlebt hat, erscheint mir, wenn nicht wie ein Toter, so doch wie ein Blinder. $\mathrm{Zu}$ empfinden, dass hinter dem Erlebbaren ein für unseren Geist Unerreichbares verborgen sei, dessen Schönheit und Erhabenheit uns nur mittelbar und in schwachem Widerschein erreicht, das ist Religiosität. In diesem Sinne bin ich religiös. Es ist mir genug, diese Geheimnisse staunend zu ahnen und zu versuchen, von der erhabenen Struktur des Seienden in Demut ein mattes Abbild geistig zu erfassen. [The most beautiful emotion we can experience is the mysterious. It is the fundamental emotion that stands at the cradle of all true art and science. He to whom this emotion is a stranger, who can no longer wonder and stand rapt in awe, is as good as dead, a snuffed-out-candle. To sense that behind anything that can be experienced there is something that our minds cannot grasp, whose beauty and sublimity reaches us only indirectly: this is religiousness. In this sense, and in this sense only, I am a devoutly religious man.] (translation Isaacson 2007:387, footnote 5)

An even more succinct expression of his stance was Einstein's response to the famous telegram from Rabbi Herbert S. Goldstein, dated April 1929 with the urgent demand: 'Do you believe in God?' to which Einstein replied: 'I believe in Spinoza's God, who reveals himself in the lawful harmony of all that exists, but not in a God who concerns himself with the fate and the doings of mankind. ${ }^{8}$

What follows is an attempt to show how Einstein's religiosity was evident from childhood and took on a specific philosophical form just as his own thinking about the cosmos. Workings of nature occupied him and he began to find correlations between these and natural laws in operation.

\section{From God to Spinoza's god: satisfying natural interpretations of the cosmos}

Einstein gives a good description of the deistic concept of God (Ben-Chaim 2011): ${ }^{9}$

My religion consists of a humble admiration of the illimitable superior spirit who reveals himself in the slight details we are able to perceive with our frail and feeble minds. That deeply emotional conviction of the presence of a superior reasoning

8.Goldstein's response to Einstein's reply was remarkably positive (cf. Jammer 1999:48ff.).

9.Einstein sometimes used a variety of phrases in speaking of God: der Herrgot [the Lord God], der Alte [the Old One]. power, which is revealed in the incomprehensible universe, forms my idea of God. ${ }^{10}$ (p. 64; cf. Isaacson 2007:384)

Isaacson (2007:4) refers to him as 'a reverential rebel ... guided by a faith, which he wore lightly ... in a God ${ }^{11}$ who would not play dice by allowing things to happen by chance'. ${ }^{12}$

\section{The early days}

At the age of nine the young Albert Einstein voluntarily adopted Jewish practices despite his parents' secular interpretation of religion and, in particular, the Jewish faith. At the time he even composed hymns to the glory of God, singing at home and on the streets he walked (Isaacson 2007:16), but at the age of 12 , through the reading of religious attempts to reconcile science and religion, he departed radically from formal religion into free thinking, convinced that the Bible stories could not be true. ${ }^{13}$

\section{Maturation of the scientist}

When the informal Akademie Olympia, comprising of Einstein, Solovine and Habicht, was formed in Bern in 1902, their joint discussions of their reading included philosophical works ${ }^{14}$. Influenced by Spinoza, 'Einstein embraced his concept of an amorphous God reflected in the awe-inspiring beauty, rationality, and unity of nature's laws' (Isaacson 2007:84) $)^{15}$. This was no personal God, but did give some direction for understanding deistic activity in the sense of determinism, so as to reasonably conclude with immutable cause and effect. Translated, it was a belief, coupled with feelings of awe and humility, in something larger than himself or anything else, for that matter (Isaacson 2007:385). This was a belief that would buttress his opposition to the randomness and indeterminacy of quantum mechanics. Even when he heard in May 1921 that Dayton Miller, using a modified Michelson-Morley technique, seemed to prove that the speed of light varied, Einstein was unfazed uttering the famous: 'Raffiniert ist der Herr Gott, aber boshaft ist der nicht' [Subtle is the Lord, but malicious He is not] ${ }^{16}$ Einstein knew that he was right and his views rightly understood God's universe in the matter. Still, towards the end of his life, resisting uncertainty and randomness (quantum mechanics), he quipped that God may possibly be a little malicious (Isaacson 2007:299).

10.Isaacson (2007:3) claims that, while Einstein was perceived as a relativist, he personally held that the goal of science 'Beneath all his theories, including relativity, was a quest for invariants, certainties, and absolutes.'

11.A Spinozian deity.

12.Bohr's famous rejoinder was, 'Einstein, stop telling God what to do!' (Isaacson 2007:326).

13.The domain of science deals with the 'how' and religion with the 'why' of issues that challenge humankind's intellectual rigour in thinking.

14.These ranged from works by Sophocles, Spinoza, Poincaré, Hume, Cervantes, Mach and others.

15.This is reminiscent of Isaac Newton on how the wonder of science reinforced his belief in a God.

16.The fireplace stonework in the faculty lounge of the mathematics department at Princeton has the quote carved in it (TODAYINSCI 2016; cf. Pais 2005:vi). But more significant for Christianity are, for instance, Warfield's insights on religionless Christianity 
It was design that intrigued Einstein as it did Spinoza. Spinoza was, however, a monist who equated a supreme God and Nature so that natural laws express and coincide with God's rational nature ${ }^{17}$ pantheistically (Dembski 1999:55). Spinoza recognised natural geometry in the architecture of nature and the finely tuned relationships between the various bodies comprising nature - to such an extent that his ethics was presented as 'a geometric way of life' (Rawes 2012:81-82). ${ }^{18}$ In my opinion, what distinguished Einstein's approach to the geometry of nature and its aesthetical display was not so much the reception of the knowledge and insights that he gleaned from Spinoza, but that he went further than that. Einstein, attracted to the idea of objective reality and divine design (Isaacson 2007:334), saw engagement with natural laws as being active and ongoing ${ }^{19}$ - a dynamic process that translated into a radical new way of seeing nature at work. ${ }^{20}$ His views were to challenge all of physics to date as well as to open doors to explore fringes of nature not adequately explained by his own or past theories. Einstein's theories also challenged traditional Christian understandings of time and space, and demanded a response to the relative nature of thinking which he had applied so successfully in formulating his natural theories.

Nevertheless, Einstein was also challenged by his own presuppositions such as the beauty of the cosmos and nature's orderliness ${ }^{21}$ that, in his view, were not contingent upon chance. In other words, God did not leave some of nature to chance. ${ }^{22}$ Buttressed by his faith in the simplicity ${ }^{23}$ and elegance of mathematical equations, which supported his particular understanding of nature, Einstein rationalised that, while quantum mechanics may prove to be right, it was as yet incomplete as a theory (Isaacson 2007:352, footnote 45,335$)$. Newton's famous statement in this regard was 'Nature is pleased with simplicity' and key to his understanding of God (Rogers 1999:233). Einstein's credo, however, did not fully share in Newton's conclusion. He never quite explained what he meant by mathematical simplicity, but seemed to rely on intuition (Isaacson 2007:352) being heavily dependent on imagination which, in this regard, in Isaacson's view, was more important than knowledge (p. 387).

17.While Spinoza was ostracised by the Jews of his day, Einstein was merely criticised. Both were accused of making statements outside of their jurisdictions (Isaacson 2007:389).

18.In addition, Spinoza saw more to the forms of substance than merely as extended matter; nevertheless, he identified the complexity of life within the material (Rawes 2012:72)

19.I am indebted to an essay by Michael Mack (2012:28ff.) which so clearly brings out the debt that Einstein, and for that matter all who pursue the aesthetic, owe to Spinoza.

20.To name but one example. The use of the term deep ecology suggests a material model similar to a theological model except that God is supplanted by $(\mathrm{N})$ nature (Smith 2012:52) - a natural third millennium development of Spinoza's geometry and aesthetics.

21.This would, of course, fly straight in the face of Flew's arguments leading to conclude with an 'Orderer' (Flew 1966:74, par. 3.30).

22.This attitude was the basis for his continued resistance to quantum theory and its indeterminacy.

23.The famous statement by Newton in this regard was 'Nature is pleased with simplicity.' Newton's understanding of simplicity was a key to his understanding of God (Rogers 1999:233)
Although his deterministic belief about nature precluded him from seeing any value in prayer, it did not deny an impersonal but immanent and cosmic spirit. But it would be a god who does not meddle in world affairs at whim (Isaacson 2007:388, 391). Isaacson suggests that this was probably largely based on his reading of Schopenhauer, expressed in Einstein's credo as 'I do not at all believe in free will in the philosophical sense' (Isaacson 2007:391, footnote 20).

A valid question is whether Einstein's language about God - he used words such as der Herrgott and der Alte was merely God-speech disguising his real naturalistic convictions. Isaacson replies to this charge that Einstein again and again debunked atheists, confessed belief in deity that 'informed and inspired, rather than conflicted with, his scientific work' (2007:389-390). In a letter to Eric Gutkind, dated 3 January 1954, Einstein famously stated: 'Science without religion is lame, religion without science is blind' (Randerson 2008).

As far as Einstein is concerned, I would suggest that a generous interpretation of his views, representative of a modernity worldview, ${ }^{24}$ would be to accept that he would have seen a deistic God as the necessary ground of being for this world and its reality. A less generous interpretation would be to simply see 'God' as a possibility for this world thus accounting for the rationality, aesthetic and design evidence, et cetera.

\section{Antony Garrard Newton Flew (1923-2010)}

\section{Flew's references to some basic premises}

Flew wrote extensively on critical thinking emphasising practical reasoning buttressed by clear thinking. It is implied for any clear thinking of a Socratic nature in any quest for truth $^{25}$ as is evident in his book How to think straight (Flew 1998). For Flew this was an indispensable standard, one by which one could measure the process in seeking after the truth of any matter pursued (Flew 1998:11, par. 1.1; also refer to the sources mentioned in footnote 26 ).

It sounds almost prophetic when one reads that Flew (1998) wrote:

that all of us constantly need to be asking ourselves what it is which we want to believe to be true, and whether our desires so to believe are stronger than our desires to know the truth, however uncongenial to us that truth may be. (p. 10)

It becomes clear that Flew accepted his own challenge. No claim is made to be exhaustive in commenting on his deeply incisive form of reasoning. The purpose is to merely illustrate

24.A pre-modern worldview does not necessarily ascribe cause and effect to natural laws. Postmodernity, on the other hand, reflects a worldview that allows for a variety of stories, whether similar or contradictory, and does not subscribe to the entitlement of any one of them.

25.For a comprehensive discussion of the arguments of rationality as used by Flew, see, for instance, Beckwith's treatment of a case for historical miracles (2003:220236) in addressing the Martin-Flew debate (also see a similar treatment of the Flew-Mackie attack in Settle 1987:181-200) or the Craig-Flew debate in Wallace 2003) 
in generic form one way of understanding Flew's arguments as these most clearly pertain to this article.

- For Flew there were a number of evident principles to consider for clear reasoning. Two of which are most clearly reflected in his personal reflection of his journey from atheism to deism/theism in his book There is a God (Flew 2007). These principles are: The Socratic principle (Socrates c. 470-399) and the principle of insufficient reason to believe.

- There is some significance, which will not be explored here, in Flew referring to the premise of 'We must follow the argument wherever it leads' (Flew 2007:22; cf. Flew1998:17, par. 19 $)^{26}$ - a principle very much in evidence in the debates hosted by the Socratic Club in Oxford. ${ }^{27}$ Later again, reiterated in his book (Flew 2007:22), he explains the significance of this principle in his journey from atheism to theism. One of the great questions that Flew had to face was the theist's address of the problem of evil of how to appeal to a forgiving God. He (Flew 1998:19, par. 1.26) wrote: 'it is for instance, logically impossible to have the good of forgiveness without the evil of an injury to be forgiven', suggestive of selfcontradiction. For Flew (1998:17-18, par. 1.19), to ignore or tolerate self-contradiction is to imply that one values something else more than truth. Insufficient reason to believe $^{28}$

This observation (Flew 2007:24) was made in the context of C.S. Lewis' influence at Oxford and, in particular, his role at the Socratic Club. Flew was left unconvinced by their arguments supportive of theism, in particular Christian theism. Indeed, almost 30 years later, such was the impact of Flew $^{29}$ in demolishing the rational defences of God by Christians that John J. Shepherd embarked upon a doctoral thesis to trace the remaining strains of these rational defences. As his research developed, Shepherd (1975: Preface) came to a surprising conclusion. I quote from his published doctoral thesis: 'I came to feel that the case for Christian theism was not after all hopeless.' What is interesting is that Flew does not deny the possibility of belief, but only if there was sufficient reason to believe. In his book (Flew 1998) he repeatedly states that while propositions may prove to be true they may also be utilised to support flawed arguments..$^{30}$ The questioning of the flow of reasoned arguments was a matter of falsification and verification (Flew 1998:36, par. 2.9). Only flawless reasoning must suffice if there is to be any possibility that a willingness to listen might lead to a possible reconsideration of belief.

26.This book served as a textbook and is basic equipment for any critical thinker. It includes 62 suggestions on how to critically evaluate evidence for and against propositions.

27.It was founded in December 1941 and disbanded in 1972. Flew presented papers at the club as other illustrious figures such as Iris Murdoch, E.L. Mascall, Michae Polanyi and A.J Ayer did. C.S. Lewis served as its first president from 1942-1954.

28. Reminiscent of the Bertrand Russel's answer to the question should God exist: 'Lord, you didn't give us enough evidence!' (Miles 1972:53).

29.Shepherd adds the works of R.W. Hepburn, C.B. Martin and W.I. Matson to Flew's own (Shepherd 1975: Preface) - all of which sought to demolish any rational approach to belief in God's existence.

30. Flew cites Charles Darwin who collected arguments against his theory of evolution This methodology ensured that Darwin could deal with these arguments and not just seek to disprove them. Consequently, Darwin was able to establish his position with more and more clarity. 'Hypotheses are tested by deducing consequences which would follow if the hypothesis were true' (Flew 1998:36, par. 2.9).
Mention could also have been made of the more inclusive deductive reasoning and formulation of propositions, but the above should suffice to make the point that Flew kept true to his own dictums. It goes without saying that the complexity of Flew's philosophical reasoning may not be reduced to two principles as above. They are merely illustrative of the more evident premises in his narration of his journey from atheism towards theism. Having said that, by the late 1990s, Flew was evidently no longer persuaded by the best arguments that could be brought against religious theism.

\section{The journey from atheism to theism Flew the unbeliever and sceptic}

C.S. Lewis's ${ }^{31}$ moral argument (1958:15-19) 32 used at the Socratic Club, which supposedly leads to conclude with a higher good, did not impress Flew. Christianity was simply not for him as it later also was not for Carrier (2005:12). ${ }^{33}$ The basic stumbling block for Flew was that Being cannot be concluded from the concept of moral good. That was flawed reasoning. Instead, he relied on Darwin's principle of evolution to underscore a type of evolutionary ethics (Flew 1997). ${ }^{34}$ Flew's examination of Christian theism (1966) will reveal his scepticism before his conversion. It is, in fact, an attack on Christian theism or theism per se (Owen 1967:282). I propose to merely state the bare essence of this argument, but it should be sufficient to identify the pattern that Flew used in discussing the inadequacy of theism and consequently of theistic belief.

Flew claimed that there is no sufficient basis to speak of god or God. ${ }^{35}$ One simply could not claim pure methodical reasoning and claim the notion of an intelligible being. In fact it did not make sense to discuss such a notion (Flew 1966:25ff.). It bears mentioning that in his early career, Flew leaned towards psychical research - following C.E.M. Joad (Flew 2007:33-34). To entertain the notion of God is to deal allows for contingencies such as hell, heaven, morality and evil to be taken seriously (cf. Flew 1966:56, par. 2., 57-58). While Flew is happy to discuss theism, it is the figure occupying the concept that is bothersome. No figure of God could be allowed to develop or Flew denied such a figure any identity. To grant even the least development would be to conclude with an identity associated with irreconcilable contradictions. How, for instance, can anyone identify

31.Lewis was also a convert from atheism to theism. His spiritual journey, however, concluded in the further conversion to Jesus Christ.

32.Lewis $(1958: 18,20)$ develops the argument from the premise of a 'Law of Nature'. From that premise he suggested belief 'in a real Right and Wrong', held to by all human beings, but not acted upon equally. Lewis then suggests that this may be reasonably accepted as a 'Rule of Decent Behaviour'. It was one step further to claim it as a foundation for morality and then to extrapolate to the further claim that the origin of this evident natural law to be God. Flew's critical response at the Socratic Club was his 1950 paper on 'Theology and falsification' (2007:42-44)

33.Carrier's spiritual journey led him into Taoism - an appreciation of agnosticism - to eventually conclude with material philosophy and its natural explanations underpinning his continued atheism.

34.The reprint of the 1984 edition has an updated preface. I, however, lean on the 1966 edition, because it reflects Flew's stance and ideas long before his conversion to theism.

35.This is the old battle between apophaticism (ideas of what god is not) as against revelationism (what god is). 
God and speak about the infinite in finite terms? To add fuel to fire the contradictions that accompany any such God must be seen in light of contradictions such as God or man's free will, infinite love or existence and consequences of evil (Flew 1966:25-29, par. 2.1-2.8).

There is in actual fact nothing new here that the historic Christian Church did not address from time to time. What is apparent, however, is that Flew, the sceptic, does not spend time dealing with the attempts towards answers by Christian theologians or apologists. He kept to his agenda and focused in particular on the matter of theodicy in the matter of attempts to speak intelligibly about God.

Conversely, how does Flew then view the existence of what he terms facts? He contends that facts have to be accepted as they are, and to require ultimate explanations from them is nonsensical. This approach (Flew 1966:83-84, par. 4.18-4.20) rejects any possible answer suggestive of non-factual theistic content. Any other view would, by inference, make speculation possible and so allow for the possibility of a hypothesis of god who, by implication, could serve as the ultimate answer. For Flew that would be flawed reasoning and, for that reason, could not logically develop into an acceptable argument. In fact, such a line of reasoning would be equivalent to enter the arena of mystical mystery. Flew (1966:102, par. 5.6) readily concludes: 'there is no necessity for God'. He is also decisive about claims of personal experience: do not withstand falsification and, for that reason, it must remain unproven. Consequently they cannot be submitted as 'truth claims'.

Is that a reasonable approach? Religious proponents have argued that the argument may be made that, while there may not be adequate proof for the objectivity of sensory experiences, the same ought to apply to religious ones. But then there has to be some way to account for the objectivity of Christian experiences in the earliest Christian records. Reasonableness needs to be factored in. The Bible, compiled from numerous manuscripts, gives a liberal account of such experiences begging interpretation.

While not comprehensive, the very brief outline above demonstrates, from Flew's standpoint, that he followed where the evidence led. But was the naturalistic cul-de-sac model satisfying to his penetrating Socratic mind and consequently careful reasoning?

\section{Flew, the convert to theism in 2004}

When discussing the existence of God, Flew held that the burden of proof lies with the side propagating theism. ${ }^{36}$ This was ably questioned by Odoj (2014:116) who traces 'presumptive theism', ${ }^{37}$ reminiscent of gathering enough

36.See, for instance, his debates with Gary R. Habermas in February 1985, Dallas Texas and in May 1985 at the Liberty University, Lynchburg, Virginia. An entry on hardcopy of Habermas, Flew \& Miethe (2003) for a transcript debating the resurrection.

37.According to Odoj (2014:116) Flew understood this in conversation as not insisting on asserting or postulating God's existence. evidence to warrant a Pascalian wager as best presented when both parties take on the same burden of proof (pp. 130-131).

Flew's conversion from atheism was the result of a spiritual journey which, for him, reached a climax in 2004 (Hazen 2004:193). The emphasis must be on the journey. Telephone conversations between Flew and Gary R. Habermas (2004) in 2003 revealed that Flew was uneasy about his present atheist position and was considering becoming a deist or theist going to where the evidence was leading. By January 2004 he had committed himself to his new views. Popular secular media responded eagerly to the news. It, however, soon became clear that Flew's shift in thinking was not sufficiently explained in the media coverage. Habermas ${ }^{38}$ offered to interview Flew (Habermas 2004:197-212). In this interview Flew explained his commitment to deism or theism. Both edited and revisited the interview during the course of the year; one of the aims being to deliver a non-technical interview that would be accessible to all eventually leading to the publication of a book (Habermas 2004).

Some matters became clear from the interview. Flew (1972) confessed his freedom in that he had to submit to his own approach to falsification. This will be briefly explicated under the following headings:

\section{- Flew's god}

An Aristotelian conception of god ${ }^{39}$ with the attributes of power and intelligence is the type of deity that Flew leaned towards (Habermas 2004:199, Flew with Varghese 2007:92, 148-154). Deity, in terms of these attributes, is proved to be inadequate in terms of traditional concepts of revelation. In the course of time Flew had to face a newer and fuller objective revelation made possible through scientific advances. Nevertheless, he made it absolutely clear that he merely leaned to the type of deity for which a case can be made. This deity of natural or scientific revelation cannot, for instance, account for justice. That, for Flew, remains a human construct for regulating social and human behaviour. Clearly Flew submitted to a scientific teleology to validate a serious consideration of theism.

- Flew on revelation

In the interview with Habermas (2004:199), Flew acknowledged that he was not averse to being labelled a 'deist', as the question of supernatural revelation would be excluded. Being a deist would also leave the door open to the continued possibility of revisiting the concept of god in light of scientific advances. This is reminiscent of Hugh Ross's statement (1999:9) ${ }^{40}$ 'Revelation is information, not persuasion, however persuasive that information may be'. In Flew's opinion, the case for intelligent design, in particular, had gained in appreciation from scientific advances: this covered a whole spectrum of disciplines ranging from physics, mathematics, biology, geology, chemistry,

38.Gary R. Habermas is a Christian philosopher and historian serving as professor of philosophy and theology at the private Liberty University, Lynchburg, Virginia.

39.There were two factors, in particular, that were decisive. One was my growing empathy with the insight of Einstein and other noted scientists that there had to be an intelligence behind the integrated complexity of the physical Universe. The second was my own insight that the integrated complexity of life itself - which is far more complex than the physical Universe - can only be explained in terms of an
intelligent Source. (Wiker 2017).

0.This may of course be critiqued in that it implies the communication of propositional knowledge about material matter. Nevertheless the quote serves to illustrate what I believe Flew meant. 
palaeontology, botany, zoology, information science, psychology and sociology and more. ${ }^{41}$

It is, of course, impossible to subject the full data spectrum of revelation pertaining to creation, verification and falsification, and for that reason it remains secondary data. Consequently, Flew continued to hold that revelation cannot support any evidence to conclude with an attribute such as goodness. His rational approach would allow for a God, but one who is a-goodness, neither good nor evil, and therefore has no or little interest in human behaviour. This point of view accounts to some extent for the evil perceived all around us. It also suggests that it excludes the tradition that would claim a deity to possess infinite goodness and, for that matter, knowledge and power.

- Flew the theist

Flew accepted a deistic position as representative of his new position, because it does not try to justify a first cause to account for the process of secondary causes in creation. This does not mean that he was not open to theistic revelation (Habermas 2004:199). He typically gives the reason for this openness: the serious entertainment that the biblical account of Genesis 1 may be considered as evidence of revelation..$^{42}$ But he seemed to shift yet again when he suggested that a hypothesis of God would best account for the origin of evolution and thus too for its consequences for the possibility of life - a move towards theism.

This position is also used to strengthen the case for design in light of the more recent advances in science, revealing how finely tuned the universe is, makes it possible for life to exist (Flew with Varghese 2007:126-127). Flew thus discounts the older evolutionary theories that exclude God, First Cause or Designer altogether. This does not mean he advocated belief in the God of the Bible or holds to its creation accounts merely that when all the evidence of complexity is weighed, the older versions of evolutionary theory and of theistic evolutionists are found wanting. Through the advances in scientific insights the understanding of natural creation, now available to scientist and layperson, also present a more plausible explanation. Flew made it clear that his conversion to theism was not to be taken as a paradigm shift, as he simply followed where the evidence leads (Flew with Varghese 2007:89).

Theism is back in the picture with Flew's new position. In this sense he challenged Dawkins's view of evolution espoused in Darwin's 14th chapter of The Origin of the Species (1861:399-432) and so failing to account for the origin of evolution of life. 'I must premise, that I have nothing to do with the origin of the primary mental powers, any more than I have with that of life itself' (Darwin 1861:185). To that end justice, morality, aesthetics, et cetera would simply add to the complexity of trying to account for anything beyond the origin of species. It is this that I understand Flew to question.

To that end one may conclude with a measure of certainty that he advanced beyond deism to theism. However, it would

41.This is reminiscent of Schroeder (1998:17) who remarks that in biology paleontology, cosmology, among a sweep of topics, the confluence is remarkable'. In addition Schroeder focuses on the fine-tuning of the universe and its design as mainstays of his argument.
main

42. His reply referred to the persuasive arguments that Gerald L. Schroeder (1998) makes. not be safe to conclude that there is a total discount of Aristotle's deity. Nor would it suffice to compare Flew's theism to equate with the God of the Bible. Flew accepted a deity that could reasonably be credited with some involvement in this universe and the world. His belief in deity was basically subject to the scientific observation that nature obeys laws for its own existence and for that of life (Flew with Varghese 2007:89). He followed where the evidence led and perceptively concluded that deity was most likely to exist within such an environment. This would be similar to the Christian perception of created reality.

\section{Conclusion}

While Einstein's deism would lean more towards

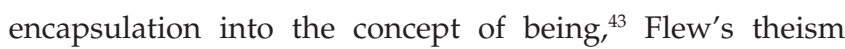
drove him beyond considering the non-materiality of natural spirituality suggested by, for instance, beauty, order, et cetera. The arguments he encountered though, were not sufficient to conclude with more than the reasonable belief of theism. As such his theism was insufficient for him to commit to the Gospel of Jesus Christ, and so claim conversion to Christ. Einstein, on the other hand, was intoxicated with the beauty of nature's reality.

Nevertheless, it is evident that deism or theism explores degrees of material or divine transcendence and immanence. For a Christian these will reflect more clearly in traditional understandings of divinity and it will be more clearly expressed in creedal and catechetical formulas. In grappling with the thoughts of these great thinkers, I was reminded again and again of Warfield's 'ineradicable sensus deitatis (divinitatis), which - so far from lying inert within him - is a fertile semen religionis; ... accordingly all men have ... religion' (1912:446-447 [italics in the original]). ${ }^{44}$ Dooyeweerd (2012) expresses this religion dynamically:

The deepest source of our view on life's fundamental issues does not lie in scientific theory, but in the religious direction of our lives. This is a matter which concerns every human being and which cannot be delegated exclusively to the theoretical sphere of scholarship. (p. 6 [italics in the original])

Einstein's deep relation with Spinoza's philosophy of god as 'in' the universe is worthy of exploring for its ecological value statements. The nature of its aesthetics not only stimulates but evokes a desire towards comprehending ecological complexities and maintaining the system of nature. In Flew's theism of God as 'beyond and in', the universe continues to challenge rational thinkers to explore questions that arise where science ultimately leads to and so face the challenge of engaging with theism. This article should encourage every Christian to dialogue with persons persuaded by deism or theism attempting to introduce such persons to the Creator God, the God of the Bible.

43.Reminiscent of Macquarie's natural theology - that to hypothesize about God debases him to object, God is Being not being. The implications for faith are of course that it is rooted in Being. At that level it is seen to be compatible to the facts of experience for explanatory purposes (Shepherd 1975:2).

44.See for instance Calvin (1845:47-48, 51-53, 43-45, I. iv. 1; cf. v. 1 ; I. iii. 1, 2; iv. 1 , 4; v. 1.) 


\section{Acknowledgments Competing Interest}

The author declares that he has no financial or personal relationships which may have inappropriately influenced him in writing this article.

\section{References}

Beckwith, F.J., 2003, 'Theism, miracles, and the modern mind', in P. Copan \& P.K. Moser (eds.), The rationality of theism, pp. 221-236, Routledge London.

Ben-Chaim, M., 2011, Religion and reason, Mesora, New York.

Calvin, J., 1845, Institutes of the Christian religion, vol. 1, Calvin Translation Society, Edinburgh.

Carrier, R., 2005, Sense and goodness without God: a defense of metaphysical naturalism, AuthorHouse, Bloomington.

Carroll, L., 2002, Alice's adventures in wonderland/Through the looking glass, ed. L. Pirè, Giunti Editore S.p.A., Firenze.

Darwin, C., 1861, On the origin of the species by means of natural selection, D. Appleton \& Company, New York.

Dembski, W.A., 1999, Intelligent design: the bridge between science and theology, InterVarsity Press, Downers Grove.

Dooyeweerd, H., 2012, Roots of Western culture: pagan, secular, and Christian options, vol. 15, Padeia Press, Grand Rapids. (Series B).

Dupré, L., 1999, 'On the intellectual sources of modern atheism', International Journal for Philosophy of Religion, Religion and Metaphysics 45(1), 1-11, viewed 21 July 2016, from http://www.jstor.org/stable/40019110

Einstein, A., 1932, Einstein's Credo: Albert Einstein in the World Wide Web, viewed 5 August 2016, from http://www.einstein-website.de/z_biography/credo.html

Flew, A., 1966, God and philosophy, Hutchinson, London.

Flew, A., 1972, 'Theology and falsification: the university discussion', in A. Flew \& A Maclntyre (eds.), New essays in philosophical theology, pp. 98-99, SCM Press Ltd, London.

Flew, A., 1997, Darwinian evolution, Transaction Publishers, New Brunswick.

Flew, A., 1998, How to think straight: an introduction to critical reasoning, Prometheus Books, New York.

Flew, A. with Roy Abraham Varghese, 2007, There is a God: how the world's most notorious atheist changed his mind, HarperOne, New York.

Habermas, G.R., 2004 'My Pilgrimage from Atheism to Theism: A Discussion between Antony Flew and Gary Habermas', Philosophia Christi, 6(2), 197-212, viewed 29 July 2016, from http://digitalcommons.liberty.edu/lts_fac_pubs/333

Habermas, G.R., Flew, A.G.N. \& Miethe, T.L., 2003, Did Jesus rise from the dead? The resurrection debate, Wipf \& Stock Publishers, Eugene.

Hazen, C.J., 2004, Editor's introduction, Philosphia Christi 6(2), 193.

Isaacson, W., 2007, Einstein: his life and universe, Simon \& Schuster Paperbacks, New York.

Jammer, M., 1999, Einstein and religion: physics and religion, Princeton University Press, Princeton.

Johnson, B., 1993, 'World Union of Deists', viewed 19 July 2016, from http://www. deism.com/deism_defined.htm

Lewis, C.S., 1958, Basic Christianity, Fontana Books, London.

Lucci, D., 2008, Scripture and deism: The biblical criticism of the eighteenth-century British deists, Peter Lang AG, European Academic Publishers, Bern.

Mack, M., 2012, 'Spinoza's non-humanist humanism', in B. Lord (ed.), Spinoza beyond philosophy, pp. 28-47, Edinburgh University Press, Edinburgh.
McGrath, A.E., 2012, Mere Apologetics, Baker Books, Grand Rapids.

Miles, T.R., 1972, Religious experience, The MacMillan Press, London.

Odoj, E., 2014, "Is "the presumption of atheism" in fact a neutral procedure? A critical examination of Antony Flew's position', Roczniki Filozoficzne/Annales de Philosophie/Annals of Philosophy 62(2), 115-132, viewed 28 July 2016, from http://www.jstor.org/stable/43410373

Oppy, G., 1992, 'Is God good by definition?' Religious Studies 28, 467-474, viewed 3 August 2016, from http://infidels.org/library/modern/graham_oppy/god.html

Owen, H.P., 1967, 'Review: Anthony Flew. God and philosophy', Religious Studies 2(2), 282-285, viewed 21 July 2016, from http://www.jstor.org/stable/20004663

Pais, A., 2005, 'Subtle is the Lord ...', the science and the life of Albert Einstein, Oxford University Press, Oxford.

Potgieter, R., 2013, 'Keith Ward's soft panentheism', In die Skriflig/In Luce Verbi, Art. \#581, 9 pages. https://doi.org/10.4102/ids.v47i1.581

Randerson, J., 2008, 'Childish superstition: Einstein's letter makes view of religion relatively clear', The Guardian, 13 May, viewed 12 September 2016 from https:// www.theguardian.com/science/2008/may/12/peopleinscience.religion

Rawes, P., 2012, 'Spinoza's architectural passages and geometric comportments', in B. Lord (ed.), Spinoza beyond philosophy, pp. 66-86, Edinburgh University Press, Edinburgh.

Rogers, G.A.J., 1999, 'Newton and the guaranteeing God', in J.E. Force \& R.H. Popkin (eds.), Newton and religion: context, nature, and influence pp. 221-234, Kluwer Academic Publishers, Dordrecht. https://doi.org/10.1007/978-94-017-2426-5_11

Rowe, W.L., 2000, 'Deism', in E. Craig \& E. Craig (eds.), The Concise Routledge Encyclopaedia of Philosophy, p. 198, Routledge, London.

Ross, H., 1999, 'General revelation: nature's testament', Philosphia Christi, 21(1) 9-16, viewed 12 September 2016, from http://www.reasons.org/articles/ philosophia-christi

Schroeder, G.L., 1998, The science of God: the convergence of scientific and biblical wisdom, The Free Press, New York.

Settle, T.W., 1987, Galileo's knife in Rationality: the critical view, ed. J. Agassi \& I.C. Jarvie, Martinus Nijhoff Publishers, Dordrecht. (Nijhoff International Philosophy series 23).

Shepherd, J.J., 1975, Experience, inference and God, The Macmillan Press, New York. https://doi.org/10.1007/978-1-349-02436-0

Smith, A.P., 2012, 'The ethical relation of bodies: thinking with Spinoza towards an affective ecology', in B. Lord (ed.), Spinoza beyond philosophy, pp. 48-65, Edinburgh University Press, Edinburgh.

Swinburne, R., 1979, The existence of God, New York, Oxford.

TODAYINSCI, 2016, viewed 2 August 2016, from http://todayinsci.com/E/Einstein Albert/EinsteinAlbert-SubtleQuote800px.htm

Van Wyk, J., 2013, 'Die uitdaging van die ateïsme en antiteïsme: 'n Teologiese gesprek met Armando Pellencin oor sy boek Ateïsme: die saak teen God (1 \& 2)', In die Skriflig/In Luce Verbi, 47(1), Art. \#536, 15 pages. https://doi.org/10.4102/ids. Skriflig/In
v47i1.536

Vartanian, A., 1949, 'From Deist to Atheist: Diderot's Philosophical Orientation 17461749', Diderot Studies 1, 46-63, viewed 21 July 2016, from http://www.jstor.org/ stable/40372264

Wallace, S.W. (ed.), 2003, Does God exist? The Craig-Flew debate, Ashgate Publishing Limited, Aldershot.

Warfield, B.B., 1912, 'Christless Christianity', The Harvard Theological Review 5(4), 423-473, viewed 08 February 2017, from http://www.jstor.org/ stable/1507229

Wartofsky, M.W., 1979, Models: representation and the scientific understanding, Boston studies in the philosophy of science, vol. 48, ed. R.S. Cohen \& M.W. Wartofsky, D. Reidel Publishing Company, Dordrecht. https://doi.org/10.1007/97894-009-9357-0

Wiker, n.d., viewed 24 February 2017, from http://strangenotions.com/flew/ 